ISSN 0258-7122 (Print), 2408-8293 (Online)

Bangladesh J. Agril. Res. 43(2): 289-299, June 2018

\title{
YIELD LOSS ASSESSMENT AND MANAGEMENT OF FOOT ROT (Sclerotium rolfsii) OF BUSH BEAN
}

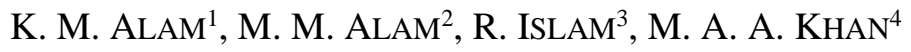 \\ AND M. N. ISLAM ${ }^{5}$
}

\begin{abstract}
The released three varieties of bush bean (BARI Jhar Shim-1, 2 and 3) were grown in both Sclerotium rolfsii inoculated and un-inoculated plots to assess the yield loss in the field of Plant Pathology Division, Bangladesh Agricultural Research Institute (BARI), Gazipur during 2013. Sclerotium rolfsii infected the bush bean plant in every growth stage and reduced the germination capacity and lessened plant vigor. The yield loss ranged from 55.43 to $64.94 \%$. A screening study was conducted to observe the resistant level of released varieties and local lines collected from On Farm Research Division (OFRD), BARI, Sylhet during 2013. B0124 and BARI Jhar Shim-3 showed susceptible and the others showed highly susceptible reaction. The antagonistic potential of the local isolates of Trichoderma harzianum against the phytopathogenic S. rolfsii was investigated in dual culture and bioassay on bean plants. Isolated T. harzianum showed antagonism effect against $S$. rolfsii and restricted around $80 \%$ mycelial growth in-vitro. A field experiment was carried out in Plant Pathology Division, BARI, Gazipur during 2014 to observe the efficacy of T. harzianum in controlling foot rot disease induced by S.rolfsii of bush bean in the field. Soil treated with $T$. harzianum mass plus seed treated with Provax 200 WP showed the lowest disease incidence $(28.47 \%)$ and the highest germination $(98.61 \%)$ and yield $(873.33 \mathrm{~kg} / \mathrm{ha})$ in compared to other treatments with pathogen inoculated soil.
\end{abstract}

Keywords: Foot rot, Sclerotım rolfsu, Trıchoderma harzıanum, Yield loss and Bush bean

\section{Introduction}

Bush bean (Phaseolus vulgaris) is cultivated commercially in Chittagong, Sylhet, North Bengal, Hill tracts and also many other places of Bangladesh. The crop is considered to be the important exporting vegetables of Bangladesh. But cultivation area and production of bush bean are reducing day by day due to several biotic and abiotic factors. Foot and root rot caused by Sclerotuum rolfsii, Fusarium oxysporum, Fusarium solani, Sclerotinia sclerotiorum and Rhizoctonia solani are a common disease problem in bush bean (Ellil et al., 1998; Rashid and Singh, 2000 and Mozumder, 2004). The foot and root rot disease resulted 0 -

\footnotetext{
${ }^{1 \& 5}$ Scientific Officer, Plant Pathology Division, Bangladesh Agricultural Research Institute (BARI), Gazipur-1701, ${ }^{2 \& 3}$ Senior Scientific Officer, Plant Pathology Division, BARI, Gazipur-1701, ${ }^{4}$ Scientific Officer, Regional Agricultural Research Station, BARI, Ishurdi, Pabna, Bangladesh.
} 
90\% plant mortality of bush bean (Chunje and Zhibiao, 1996). In Bangladesh, foot rot disease caused by $S$. rolfsii is one of the important limiting factors in bush bean production. Among the major diseases, foot rot of bush bean caused by $S$. rolfsii is economically important one. The pathogen is a soil inhabitant, polyphagous and facultative fungal parasite. It is documented that the fungus has host range of 500 plant species (Punja, 1985). S. rolfsii is predominantly distributed in tropical and subtropical countries. It is common in rainy season, when warm temperature and high relative humidity exist. Garret (1956) reported that the fungus survived in the soil for many years by producing sclerotial bodies and causing the disease either in the form of stem rot or foot rot or root rot in addition to leaf blight on several of its hosts.

There is no clear estimation report on yield loss of bush mean due to $S$. rolfsii and also, lack of knowledge about pathogenesis of this disease. Using resistant line is the best way to control disease and reduce yield loss. Besides, S. rolfsii is soil borne pathogen, in most of the cases; this disease is difficult to control by any chemical means. Many approaches have been exploited for the management of this disease. Management of foot rot has been accomplished primarily by the application of chemical fungicides but not considered to be long-term solutions, due to its high cost, exposure risks, residual toxicity and other health and environmental hazards. In an attempt to overcome this problem, some alternative methods of control may be adopted.

Biological control of plant diseases has been the subject of extensive research in the last two decades. Trichoderma spp. is well documented as effective biological control agents of plant diseases (Sivan et al., 1984 and Coley-Smith et al., 1991). Control of soil borne plant pathogens including $S$. rolfsii can be achieved by different fungicides, soil fumigants (methyl bromide) and bioagents. Because of toxicity of these compounds, there is a general trend to reduce the amount of application in the soil. S. rolfsii is an economically important pathogen on numerous crops worldwide. It has an extensive host range; at least 500 species in 100 families are susceptible, the most common hosts are legumes, crucifers, and cucurbits, and commonly occurs in the tropics, subtropics, and other warm temperate regions (Punja, 1985).

Trichoderma harzianum was found to be an effective biological control agent for reducing yield loss due to disease induced by $S$. rolfsii under both greenhouse and field conditions (Elad et al., 1980 and Ciccarese et al., 1992).

Therefore, the present study was undertaken to estimate the actual yield loss caused by foot rot disease to commercial varieties of bush bean, to isolate the bio-agent, Trichoderma in agricultural fields and to evaluate its potential in controlling $S$. rolfsii, to develop sustainable management approach (es) against foot rot disease and to reduce yield loss of bush bean. 


\section{Materials and Methods \\ Collection of bush bean seed}

Three varieties namely, BARI Bush bean 1, BARI Jhar Shim-2 and BARI Jhar Shim-3 were collected from Horticultural Research Center (HRC), BARI, Gazipur. Five local lines were collected from On Firm Research Division (OFRD), BARI, Sylhet.

\section{Pathogen isolation}

The pathogen was isolated from collar region of infected bush bean plant. At first, sample was washed thoroughly under running tap water to remove attached soil. Then sample was surface sterilized by using $20 \%$ Clorox for $2 \mathrm{~min}$. Then Clorox was washed out twice by submerging in sterilized distiled water for 2 min. Sterilized pieces was placed on water agar plate and blotter plate and kept in growth chamber at $25^{\circ} \mathrm{C}$. After three days, mycelium growth on samples was isolated and put on PDA containing plate and kept in growth chamber at $25^{\circ} \mathrm{C}$. After purification, isolate of $S$. rolfsii was preserved in PDA containing slant at $20^{\circ} \mathrm{C}$.

\section{Trichoderma isolation and identification}

Soil samples were collected from bush bean disease infected field of OFRD, BARI, Sylhet. The collected rhizospheric soil samples were used for isolation of Trichoderma sp. through dilution plate method in PDA (Elad et al., 1983) and the morphologically different colonies from each medium were picked up and purified (Johnson and Elory, 1972). They were allowed to sporulate under temperature of $28 \pm 2^{\circ} \mathrm{C} ; 12 \mathrm{hrs}$. dark and $12 \mathrm{hrs}$. light.

\section{Mass preparation of inoculum}

Inoculums of the $S$. rolfsii and T. harzianum isolates were prepared on autoclaved moist wheat bran in $1000 \mathrm{ml}$ Erlenmeyer flask. Before using the wheat bran was soaked in water for 12 hours @ 2:1 (w/v). Then it was sterilized in autoclave at $121^{\circ} \mathrm{C}$ under $1.1 \mathrm{~kg} / \mathrm{cm}^{2}$ pressures for 40 minutes. Five-millimeter diameter mycelial discs were cut from the edge of three days old PDA cultures in Petri dishes. Thirty to thirty five discs of $S$. rolfsii and $T$. harzianum were added to autoclaved wheat bran individually in the flasks and incubated at $25{ }^{\circ} \mathrm{C}$ for 14 days. It was shaken by hand at 2-3 days interval for proper colonization. The colonized wheat bran was air dried for 2 days and stored at $4{ }^{\circ} \mathrm{C}$ for further work.

Observation on yield loss of bush bean varieties due to infection of foot rot disease

This study was conducted in the field on Plant Pathology Division, BARI, during winter 2013. This study was carried out following RCBD with 3 replications. 
Three BARI released varieties were grown on uninfected and disease infected plots. Inoculum mass of $S$. rolfsii was uniformly $\left(20 \mathrm{~g} / \mathrm{m}^{2}\right)$ mixed with soil before 15 days of seed sowing in disease infected plots.

\section{Observation of disease reaction of $S$. rolfsii against local lines of bush bean}

The study was conducted in seed bed during winter 2013, on infected soil with $S$. rolfsii $\left(20 \mathrm{~g} / \mathrm{m}^{2}\right)$. Five local lines and BARI Jhar Shim-3 were used in this study. Seven seeds in a line were sown in seed bed. This study was undertaken following RCBD with 3 replications where each replication contains three lines. Disease reaction of foot rot disease was graded at 0-4 scale as described by Chester (1950) where, $0=$ no disease (I), $1=5 \%$ plants infected $(\mathrm{R}), 2=6-25 \%$ plants infected (MR), $3=26-50 \%$ plants infected $(\mathrm{S})$ and $4=51-100 \%$ plants infected (HS). Germination of BARI Jhar Shim-3 and other lines were tested in laboratory of Plant Pathology Division, BARI during August, 2013. One hundred seeds of each variety and line were used in this test. Ten seeds were placed on a water soaked blotting paper in plate. Germination percentage was counted after 7 days of seed placing on blotting paper.

\section{In vitro dual culture assay of $T$. harzianum against $S$. rolfsii}

Three days young mycelial discs of $T$. harzianum isolate of $5 \mathrm{~mm}$ diameter were cut from the peripheries of expanding colonies grown on PDA with a cork borer. Three discs of $T$. harzanum were placed at the edges of each plate poured with $15 \mathrm{ml}$ PDA and one disc of $S$. rolfsii at the centre. All plates were incubated in the dark at for $28 \pm 2^{\circ} \mathrm{C}$ until the mycelium of $S$. rolfsii fully covered the control.

\section{Efficacy of $T$. harzianum against $S$. rolfsii in field}

A field study was conducted in field of Plant Pathology Division, BARI, Gazipur during 2014. BARI Jhar Shim-3 was used in this study. Inoculum mass of $S$. rolfsii was uniformly $\left(20 \mathrm{~g} / \mathrm{m}^{2}\right)$ mixed with soil before 15 days of seed sowing. Five treatments with three replications were used following RCBD. Treatments were 1) control (without pathogen inoculation) $\left.\left(\mathrm{T}_{1}\right), 2\right)$ control (with pathogen inoculation) $\left.\left(\mathrm{T}_{2}\right), 3\right)$ soil treatment with Provax $200 \mathrm{WP}$ (Carbixin+Thiram) @ $\left.0.2 \%\left(\mathrm{~T}_{3}\right), 4\right)$ soil treated with $T$. harzianum mass $\left(20 \mathrm{~g} / \mathrm{m}^{2}\right)\left(\mathrm{T}_{4}\right)$ and 5) Seed treatment with Provax 200 WP (Carbixin+Thiram) @ 0.2\% + Soil treated with $T$. harzianum mass $\left(20 \mathrm{~g} / \mathrm{m}^{2}\right)\left(\mathrm{T}_{5}\right)$. S. rolfsii and T. harzianum mass was uniformly mixed with soil before 15 and 3 days of seed sowing, respectively.

\section{Observations and data analysis}

The statistical analysis of data was carried out using standard analysis of varianceANOVA by using MSTAT-C software (Russel and Eisensmith, 1993). To determine the significance of the difference between the means of two treatments, least significant difference (LSD) was computed at 5\% probability level. 


\section{Results and Discussion}

\section{Yield loss of commercial Bush bean varieties due to infection foot rot disease}

To observe the effect on yield of commercial bush bean varieties due to foot rot disease, three BARI released varieties were tested under inoculated condition. It was observed that $S$. rolfsii infected the bush bean in every stage of growth. $S$. rolfsii had effect on the germination of Bush bean. Germination percentage of BARI Bush bean 1, 2 and 3 were 91.66, 94.44 and 95.83\% in uninfected plots whereas those were $63.89,66.67$ and $72.22 \%$ in infected plots, respectively (Table 1).

Table 1. Effect of $S$. rolfsii on germination and yield of three varieties of bush bean

\begin{tabular}{|c|c|c|c|c|}
\hline Varieties & Treatment & Germination (\%) & Yield (kg/ha) & Yield loss (\%) \\
\hline \multirow{2}{*}{$\begin{array}{l}\text { BARI Jhar } \\
\text { Shim-1 }\end{array}$} & Uninfected & $91.66 \mathrm{a}$ & $1082 \mathrm{~b}$ & \multirow[b]{2}{*}{64.94} \\
\hline & $\begin{array}{c}\text { Pathogen } \\
\text { infected }\end{array}$ & $63.89 \mathrm{c}$ & $379.33 \mathrm{~d}$ & \\
\hline \multirow{2}{*}{$\begin{array}{l}\text { BARI Jhar } \\
\text { Shim-2 }\end{array}$} & Uninfected & $94.44 \mathrm{a}$ & $1056 \mathrm{~b}$ & \multirow[b]{2}{*}{61.74} \\
\hline & $\begin{array}{c}\text { Pathogen } \\
\text { infected }\end{array}$ & $66.67 \mathrm{bc}$ & $404 \mathrm{~d}$ & \\
\hline \multirow{2}{*}{$\begin{array}{l}\text { BARI Jhar } \\
\text { Shim-3 }\end{array}$} & Uninfected & $95.83 \mathrm{a}$ & $1139.66 \mathrm{a}$ & \multirow[b]{2}{*}{55.43} \\
\hline & $\begin{array}{c}\text { Pathogen } \\
\text { infected }\end{array}$ & $72.22 \mathrm{~b}$ & $508 \mathrm{c}$ & \\
\hline $\operatorname{LSD}(0.5 \%)$ & & 5.81 & 41.83 & \\
\hline $\mathrm{CV}(\%)$ & & 4.18 & 3.19 & \\
\hline
\end{tabular}

*Values within a column with a common letter do not differ significantly $(\mathrm{P}=0.05)$.

Table 2. Disease incidence in $S$. rolfsii infected and uninfected field on three varieties of bush bean released by BARI.

\begin{tabular}{|c|c|c|c|c|c|}
\hline Varieties & Treatment & $\begin{array}{l}\text { No. of } \\
\text { Cotyledon } \\
\text { infected } \\
\text { plant }\end{array}$ & $\begin{array}{c}\text { No. of twig } \\
\text { or first leaf } \\
\text { infected plant }\end{array}$ & $\begin{array}{l}\text { No. of collar } \\
\text { region } \\
\text { infected plant }\end{array}$ & $\begin{array}{l}\text { Total Disease } \\
\text { incidence }(\%)\end{array}$ \\
\hline \multirow{2}{*}{$\begin{array}{l}\text { BARI Jhar } \\
\text { Shim-1 }\end{array}$} & Uninfected & 0.33 & 0 & 3 & $15.27 \mathrm{c}$ \\
\hline & $\begin{array}{c}\text { Pathogen } \\
\text { infected }\end{array}$ & 2.66 & 2.66 & 7.33 & $62.5 \mathrm{a}$ \\
\hline \multirow{2}{*}{$\begin{array}{l}\text { BARI Jhar } \\
\text { Shim-2 }\end{array}$} & Uninfected & 0.33 & 0 & 3.33 & $13.19 \mathrm{c}$ \\
\hline & $\begin{array}{c}\text { Pathogen } \\
\text { infected }\end{array}$ & 3.33 & 2.33 & 6.66 & $59.03 \mathrm{a}$ \\
\hline \multirow{2}{*}{$\begin{array}{l}\text { BARI Jhar } \\
\text { Shim-3 }\end{array}$} & Uninfected & 0 & 0.33 & 2.33 & $9.72 \mathrm{c}$ \\
\hline & $\begin{array}{c}\text { Pathogen } \\
\text { infected }\end{array}$ & 2.00 & 1.66 & 4.66 & $45.83 \mathrm{~b}$ \\
\hline LSD 0.5\%) & & & & & 6.98 \\
\hline $\mathrm{CV}(\%)$ & & & & & 11.64 \\
\hline
\end{tabular}

*Values within a column with a common letter do not differ significantly $(\mathrm{P}=0.05)$ 


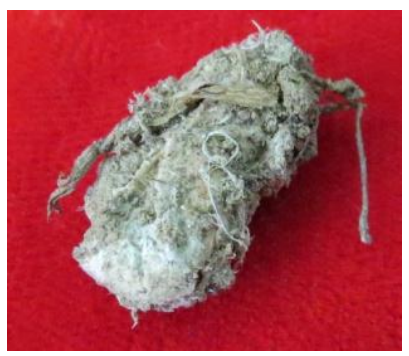

$\mathbf{a}$

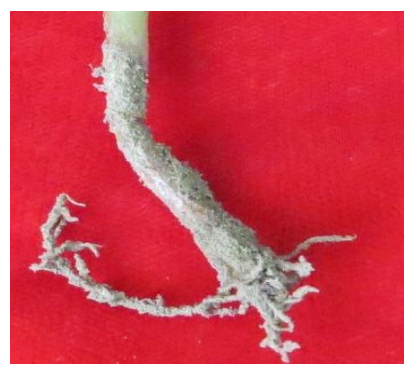

d

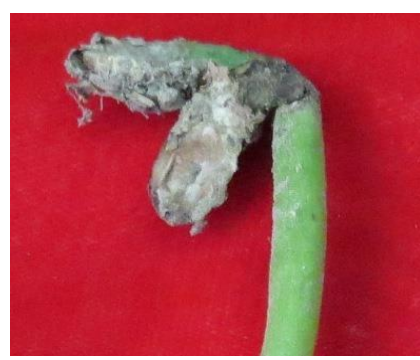

b

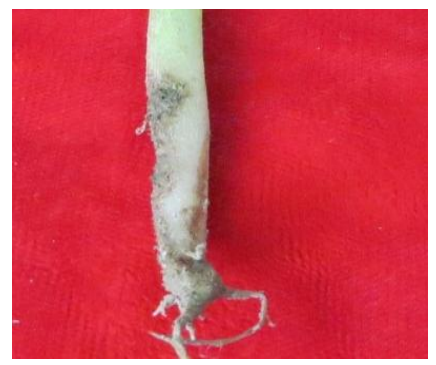

$\mathbf{e}$

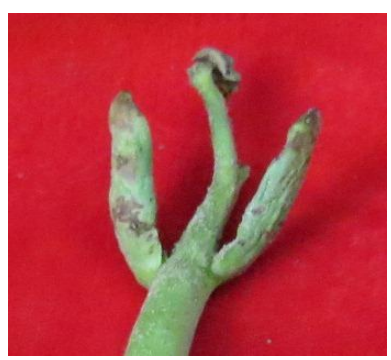

c

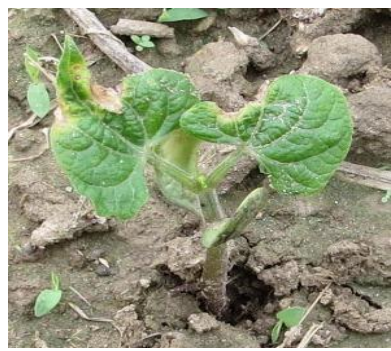

$\mathbf{f}$

Fig. 1. a) Mycelial mass cover the seed under soil, b) Germinated seedling with cotyledon infection, c) Deformed twig, d,e) Infected collar region of established plant and f) First leaf infection.

It was also observed that plant infected at early stage (cotyledon infection and twig infection) reduced the vigor of plant producing fewer branches, flowers and pods than healthy one. The higher disease incidence $(62.5 \%)$ was observed in disease infected plot of BARI Jhar Shim-1 followed by BARI Jhar Shim-2 (59.03\%). BARI Jhar Shim-3 showed to some extent tolerant against $S$. rolfsii compared to other varieties (Table 2). BARI Jhar Shim-3 also showed lowest yield loss $(55.43 \%)$ under inoculated condition which were 64.94 and $61.74 \%$ in variety 1 and 2, respectively (Table 1 ). It was observed that $S$. rolfsii infect seed under soil and form mycelial mass around seed (Fig 1 a). Some seed were germinated with cotyledon lesion (Fig $1 \mathrm{~b}$ ), deformed twig infection (Fig 1c) and first leaf blight (Fig $1 \mathrm{f}$ ) and resulted poor vigor and yield. S. rolfsii infected the collar region of the established plant and produce black lesion (Fig 1d,e) and reduced the yield potentiality. The yield loss of groundnut caused by $S$. rolfsii was $25 \%$, but sometimes it reached to $80-90 \%$ (Grichar and Bosweel, 1987). Southern blight disease caused by $S$. rolfsii reduced $50-50.3 \%$ yield of different cultivars of cowpea (Fery and Dukes, 2002).

\section{Disease reaction of $S$. rolfsii against local lines of Bush bean}

To determine the reaction of local bush bean germplasm, five local and BARI Jhar Shim-3 varietie against $S$. rofsii were checked. It was found that the collected seeds were vigor and showed high germination capacity $(96-100 \%)$ in 
blotting paper test. The lowest disease incidence (44.44\%) was observed in B0124 followed by BARI Jhar Shim-3 (47.61\%) and B0122 (55.55\%). B0123 showed the highest disease incidence $(79.36 \%)$ but was statistically similar to that of B0121 (69.84\%) (Table 3). All accessions were highly prone to S. rolfsii and disease reaction was within susceptible to highly susceptible range. This may be due to seed cotyledon of bush bean contains high amount of starch along with its soft and succulent stem.

Table 3. Reaction of some Bush bean lines and varieties against $S$. rolfsii

\begin{tabular}{l|c|c|c}
\hline \multicolumn{1}{c|}{ Varieties/Lines } & Germination $(\%)$ & $\begin{array}{c}\text { Dissease incidence } \\
(\%)\end{array}$ & $\begin{array}{c}\text { Disease } \\
\text { reaction }\end{array}$ \\
\hline B0121 & 97 & $69.84 \mathrm{a}$ & $\mathrm{HS}$ \\
B0122 & 99 & $55.55 \mathrm{abc}$ & $\mathrm{HS}$ \\
B0123 & 98 & $79.36 \mathrm{a}$ & $\mathrm{HS}$ \\
B0124 & 100 & $44.44 \mathrm{c}$ & $\mathrm{S}$ \\
B0125 & 96 & $57.14 \mathrm{~b}$ & $\mathrm{HS}$ \\
BARI Bush bean 3 & 100 & $47.61 \mathrm{bc}$ & $\mathrm{S}$ \\
\hline CV (\%) & \multicolumn{3}{c}{9.04} \\
\hline
\end{tabular}

*Values within a column with a common letter do not differ significantly $(\mathrm{P}=0.05)$

Trichoderma sp. identification and In vitro dual culture assay of $T$. harzianum against $S$. rolfsii

To find out potential Trichoderma sp., Trichoderma isolates were collected from soil. It was found that isolated Trichoderma produced white mycelium on PDA containing plate and after 3 days of growth, it gave huge sporulation and turned into light green. Hyphae was hyaline and conidiophores branched in a pyramidal fashion, with short branches near the tip and longer branches in the lower part; branching were more or less at $90^{\circ}$ angles. Phialides were in whorls of 3-5, flaskshaped, abruptly attenuated near the ends (Fig 2 a). Conidia were round shaped, smooth-walled. This above character indicates that isolated Trichodrerma belongs to species T. harzianum.

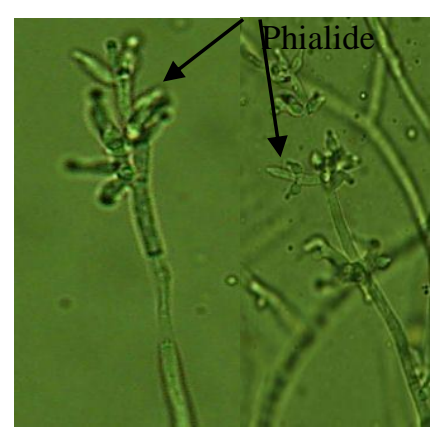

$\mathbf{a}$

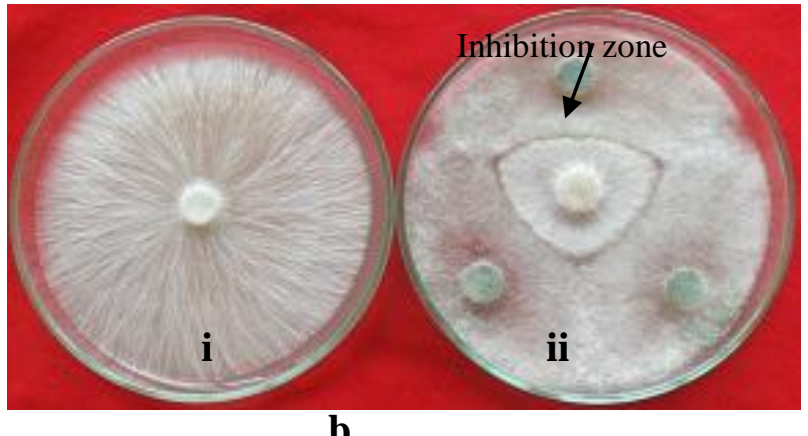

b

Fig. 2. a) Microscopic view of $T$. harzianum, b,i) $S$. rolfsii growth 72 hours after incubation at $25^{\circ} \mathrm{C}$ and b,ii) Dual assay plate $S$. rolfsii and $T$. harzianum. 
Similar identifying characters were reported by Rifai (1969). Mycelium of $S$. rolfsii covered full PDA plate after 72 hours of incubation at $25^{\circ} \mathrm{C}$ (Fig $2 \mathrm{~b}, \mathrm{i}$ ). $T$. harzianum showed about $80 \%$ growth inhibition of $S$. rolfsii and produced clear inhibition zone (Fig 2 b,ii). Inhibition zone production indicated that $T$. harzianum may produce antibiotic or toxic substance against $S$. rolfsii. Major mechanisms involved in the biocontrol activity of Trichoderma spp. are competition for space and nutrients, production of diffusible and/or volatile antibiotics and hydrolytic enzymes like chitinase and $\beta-1,3-$ glucanase. These hydrolytic enzymes partially degrade the pathogen cell wall and leads to its parasitization (Kubicek et al., 2001). This process of mycoparasitism limits growth and activity of plant pathogenic fungi. In addition, several evidences have shown that the production of some lytic enzymes is induced during the parasitic interaction between Trichoderma spp. and some pathogenic fungi (Haran et al., 1996). The chitinolytic system of T.harzianum consists of five to seven distinct enzymes, depending on the strain (Haran et al., 1995). Adhikari et.al., (2014) also reported that Trichoderma sp can inhibit around $75 \%$ growth of S. rolfsii on PDA.

\section{Efficacy of $T$. harzianum against $S$. rolfsii in field}

The treatments had significant effect on plant height. The highest plant height $(17.27 \mathrm{~cm})$ was observed in $\mathrm{T} 1$ when the plots were kept without pathogen inoculation followed by $\mathrm{T}_{5}(16.77 \mathrm{~cm})$ where integration of seed treatment with Provax + soil treated with T. harzianum, and soil treated with $T$. harzianum $\left(\mathrm{T}_{4}\right)$ $(15.27 \mathrm{~cm})$. Soil treated with Provax $\left(\mathrm{T}_{3}\right)$ showed statistically similar plant height $(10.13 \mathrm{~cm})$ as compared to diseased plot $\left(\mathrm{T}_{2}\right)$ which gave the lowest plant height $(9.50 \mathrm{~cm})$. The treatments had significant influence on number of branch per plant. The highest 6.33 branches per plant was observed in $\mathrm{T}_{1}$ (uninfected) followed by $\mathrm{T}_{5}$ where integration of seed treatment with Provax + soil treated with $T$. harzianum (6.00 branches), and soil treated with $T$. harzianum $\left(\mathrm{T}_{4}\right)(5.67$ branches). Both soil treated with Provax $\left(\mathrm{T}_{3}\right)$ and control infected plots $\left(\mathrm{T}_{2}\right)$ showed similar but the lowest (2.66) number of branches. Number of pod plant ${ }^{-1}$ varied significantly among the treatments. The highest (9.33) pods plant ${ }^{-1}$ was recorded in $\mathrm{T}_{1}$ followed by $\mathrm{T}_{5}\left(8.66\right.$ pods plant $\left.{ }^{-1}\right)$ and $\left(7.33\right.$ pods plant $\left.{ }^{-1}\right)$. Soil treated with Provax $\left(\mathrm{T}_{3}\right)$ showed statistically similar result (2.66 pods/plant) as compared to that of control infected plot $\left(\mathrm{T}_{2}\right)$ (2.33 number of pods plant $\left.{ }^{-1}\right)$ (Table 4).

The highest (113.06 g) 100 seeds weight was recorded in $\mathrm{T}_{1}$ treated plot which was statistically similar to that of with $\mathrm{T}_{5}(111.02 \mathrm{~g})$, while the lowest $(86.67 \mathrm{~g})$ 100 seeds was found in $T_{2}$ followed by $T_{3}(87.67 \mathrm{~g}$ ) (Table 4). Sothern blight disease of cowpea caused by $S$. rolfsii reduced pod numbers and dry-seed yields (Fery and Dukes, 2002). 
Table 4. Effect of different treatments on plant height, number of branches and pods per plant and 100 seeds weight of bush bean

\begin{tabular}{l|c|c|c|c}
\hline \multicolumn{1}{c|}{ Treatments } & $\begin{array}{c}\text { Plant } \\
\text { height } \\
(\mathrm{cm})\end{array}$ & $\begin{array}{c}\text { No. of } \\
\text { branches/plant }\end{array}$ & $\begin{array}{c}\text { No. of } \\
\text { pod/plant }\end{array}$ & $\begin{array}{c}100 \text { seeds } \\
\text { weight }(\mathrm{g})\end{array}$ \\
\hline $\begin{array}{l}\text { T1 = Control (without } \\
\text { pathogen inoculation) }\end{array}$ & $17.27 \mathrm{a}$ & $6.33 \mathrm{a}$ & $9.33 \mathrm{a}$ & $113.06 \mathrm{a}$ \\
$\begin{array}{l}\text { T2 = Control (with } \\
\text { pathogen inoculation) }\end{array}$ & $9.50 \mathrm{~b}$ & $2.66 \mathrm{~b}$ & $2.33 \mathrm{c}$ & $86.67 \mathrm{c}$ \\
$\begin{array}{l}\text { T3 = Soil treatment with } \\
\text { Provax 200 wp }\end{array}$ & $10.13 \mathrm{~b}$ & $2.66 \mathrm{~b}$ & $2.66 \mathrm{c}$ & $87.67 \mathrm{c}$ \\
$\begin{array}{l}\text { T4 = Soil treated with } T . \\
\text { harzianum mass }\end{array}$ & $15.27 \mathrm{a}$ & $5.67 \mathrm{a}$ & $7.33 \mathrm{~b}$ & $104.03 \mathrm{~b}$ \\
$\begin{array}{l}\text { T5 =Seed treatment with } \\
\text { Provax 200 wp + Soil } \\
\text { treated with }\end{array}$ & $16.77 \mathrm{a}$. & $6.00 \mathrm{a}$ & $8.66 \mathrm{ab}$ & $111.02 \mathrm{a}$ \\
harzianum mass & & & \\
\hline CV $(\%)$ & & & \\
\hline
\end{tabular}

*Values within a column with a common letter do not differ significantly $(\mathrm{P}=0.05)$

The un-inoculated plot $\left(\mathrm{T}_{1}\right)$ showed the lowest disease incidence $(10.06 \%)$ as well as highest $99.03 \%$ germination along with $1185.67 \mathrm{~kg}$ yield $\mathrm{ha}^{-1}$. On the other hand, the highest disease incidence $(45.83 \%)$ as well as lowest germination percentage $(75.69 \%)$ and yield $(524.67 \mathrm{~kg} / \mathrm{ha})$ was recorded in the inoculated plot $\left(\mathrm{T}_{2}\right)$. In disease inoculated condition, integrated approach (seed treatment with Provax $200 \mathrm{wp}+$ Soil treated with $T$. harzianum mass) showed the lowest disease incidence $(28.47 \%)$ as well as highest germination percentage $(98.61 \%)$ and yield (873.33kg/ha) (Fig. 3).

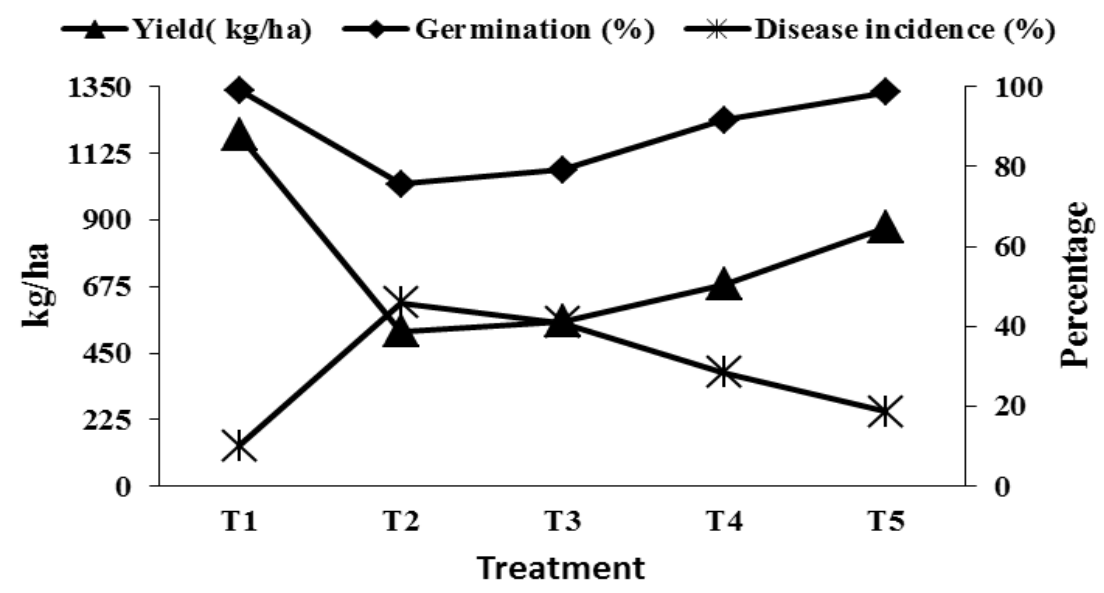

Fig. 3. Effect of treatment on germination, disease incidence and yield of Bush bean. 
Different species of Trichoderma have the potential to control soil-borne plant pathogens more effectively than chemicals and they also exhibit plant-growth promoting activity (Harman and Bjorkman, 1998). Trichoderma spp. produce extracellular $\beta-(1,3)$ - glucanases, chitinases, lipases, and proteases when they are grown on cell walls of pathogenic fungi (Haran et al., 1995). Elad et al. (1980) found that a wheat-bran preparation of T. harzianum applied to fields at rates of $500-1500 \mathrm{~kg} / \mathrm{ha}$, reduced the incidence of diseases caused by S. rolfsii. $T$. harzianum reduced 6.7-45.0\% root rot infection of bean under field condition (Ellil et al., 1998) and 66.8\% collar rot of sunflower under greenhouse condition (Prasad and Rangeshwara, 1999) when soil was artificially inoculated by $S$. rolfsii.

\section{Conclusion}

It may be concluded that released varieties and collected local bush bean lines were highly prone to foot rot disease caused by $S$. rolfsii. It can be opined that $T$. harzianum was effective in controlling foot rot disease of bush bean both in invitro and field conditions. Soil treatment by $T$. harzianum showed higher efficacy when seeds treated with Provax 200 WP.

\section{References}

Adhikari, A., S. Nandi, S. Dutta, I. Bhattacharya and T. Mandal. 2014. Study of morphology and mycoparasitism of some antagonists of Trichoderma sp. from West Bengal, India. In. J. Res. 1: 9.

Chester, K. S. 1950. Plant disease losses: their appraisal and interpretation. Plant Dis. Rep. Supplement. 190-198 (S193): 190-362.

Chunje, L. and N. Zhibiao. 1996. Occurrence and damage of foot rot in spring broad bean in Linxia area. Plant Protect. 22(6): 25-26 pp.

Ciccarese, F., S. Frisullo, M. Amenduni and M. Cirulli. 1992. Biological control of Sclerotium rolfsii root rot of sugar beet with Trichoderma harzianum. (Eds.): E.C. Tjamos, G.C. Papavizas and R.J. Cook. Plenum Press, New York. pp. 243-248

Coley-Smith, J. R., C. J. Ridout, C. M. Mitchell and J. M. Lynch.1991. Control of button rot disease of lettuce (Rhizoctonia solani) using preparations of Trichoderma viride, T. harzianum or tolclofos-methy. Plant Pathology. 40: 359-366.

Elad, Y., I. Chet, and J. Katan.1980. T. harzianum: A biocontrol agent effective against $S$. rolfsii and Rhizoctonia solani. Phytopathology. 70(2):119-121

Elad, Y., I. Chet, P. Boyle and Y. Henis. 1983. Parasitism of Trichoderma species in Rhizoctonia solani and S. rolfsii-Scanning electron microscopy and fluorescence microscopy. Phytopathology. 73: 85-88.

Ellil, A. A. H., N. G. H. Awad, and S. T. A. El-Haleam. 1998. Biocontrol of vegetable root rot disease by Trichoderma harzianum and $T$. viride role of sugars, protein and amino acids in host resistance. African J. Mycol. Biotechnol. 6 (2): 25-41. 
Fery R. L., and P. D. Dukes Sr. 2002. Southern blight (Sclerotium rolfsii Sacc.) of cowpea: yield-loss estimates and sources of resistance. Crop Protection. 21: 403408.

Garret, S. D. 1956. Biology of root infecting fungi. Cambridge University Press, 293p.

Grichar, V. J. and T. E. Bosweel. 1987.Comparison of Lorsban and Tilt WithTerrachlor For Control of Southern Blight on Peanut the Texas. Agriculture Experiment Station, Pr-4534.

Haran, S., H. Schickler, A. Oppenheim and I. Chet. 1995. New components of the chitinolytic system of Trichoderma harzianum. Mycological Res. 99: 441-446.

Harman, G. E. and T. Bjorkman. 1998. Potential and existing uses of Trichoderma and Gliocladium for plant disease control and plant growth enhancement. Taylor and Francis, London, United Kingdom. pp. 229-264

Johnson, L. F. and C. A. Elroy. 1972. Methods for Research on the Ecology of SoilBorne Plant Pathogens. 426 So. Sixth St., Minneapolis, MN 55415: Burgess Publishing Company. 247p

Kubicek, C. P., R. L. Mach, C. K. Peterbauer and M. Lorito. 2001. Trichoderma: From genes to biocontrol. J. Plant Pathology. 83: 11-23.

Mozumder, S. N. 2004. Unnata Padhatite Jharsheemer Chash (Bangla). Krishikatha, 63 (9): 269-273

Prasad, D. and R. Rangeshwaran. 1999. Granular formulation of Trichoderma and Gliocladium spp. in control of chickpea. J. Mycol. Pl. Pathol. 29 (2): 222-229.

Punja, Z. K. 1985. The biology, ecollogy, and control of Sclerotium rolfsii. Annual Review of Phytopathology. 23: 97-127.

Rashid, M. A. and D. P. Singh. 2000. A Manual on vegetable seed production in Bangladesh. AVRDC-USAID--Bangladesh Project, Horticulture Research Centre, Bangladesh Agricultural Research Institute, Joydebpur, Gazipur, Bangladesh. 73 p.

Rifai, M. A. 1969. A revision of the genus Trichoderma. Mycol Pap. 116:1-56.

Russel, D. F. and P. S. Eisensmith.1993. MSTAT-C. Crop and Soil Science Department, Michigan State University,USA. Pp.1-54

Sivan, A., Y. Elad and I. Chet. 1984. Biological control effects of a new isolate of Trichoderma harzianum on Pythium aphanidermatum. J. Phytopathology. 74: 498501. 
